\title{
岩盤・地盤条件を考慮した設計用エネルギスペクトルの提案
}

\section{A PROPOSAL OF DESING ENERGY SPECTRA ALLOWING FOR ROCK AND SOIL CONDITIONS}

\author{
秋山宏*, 楊 志勇**, 北村春幸*** \\ Hiroshi AKIYAMA, Zhi Yong YANG and Haruyuki KITAMURA
}

The loading effect of earthquakes to structures is evaluated in terms of energy spectra. The energy spectra of seismic motions in the deep rock is assumed to be of the simplest form. The seismic motions in the deep rock are amplified due to the process of wave propagation through base rocks and sedimentary soils upon the rock. The well-established wave propagation theory is applied to the seismic motions in the deep rock and the energy spectra for the surface seismic motions are estimated for the practical design purposes.

Keywords : energy input, energy spectrum, ground condition, wave propagation, amplification characteristics, synthetic seismic wave エネルギ入力, エネルギスペクトル, 地盤条件, 波動伝達, 增幅特性, 人工地震波

1. 序

地震動の構造物への荷重効果はエネルギ入力によって 最も端的にとらえることができる。その理由は下記のと おりである”。

1）地震動のフーーリエ加速度振幅スペクトルは，無减衰 弾性 1 質点系への総エネルギ入力 $E$ の次式による速度 換算值 $V_{E}$ と固有周期 $T$ との関係に一致する。

$$
V_{E}=\sqrt{\frac{2 E}{M}}
$$

2）一つの地震動による一つの構造物への総エネルギ入 力 $E$ の $(1)$ 式による速度換算值 $V_{E}$ と構造物の 1 次固 有周期 $T$ との関係を地震動の一つの構造物におけるエ ネルギスペクトルと定義する。減衰系ないし，弹塑性系 のような非線形系におけるエネルギスペクトルは，地震 動のフーリエ加速度振幅スペクトルを周期に関して平滑 化したものに対応する。平滑化の程度は，構造物の非線 形性の程度に比例する。

3）弾塑性系におけるエネルギスペクトルは， $h=0.1$ なる弾性 1 質点系におけるエネルギスペクトルで代表さ れる。hは減衰定数である。この意味において，一つの 地震動により構造物に投入されるエネルギの総量は, 専 ら, 構造物の総質量, 1 次固有周期に依存し, 構造物の 強度, 強度分布, 剛性分布, 質量分布, 復元力特性に影 響されない安定した量であると言える。
地震動の発生のメカニズムは現在次のように考えられ ている。

1）震源域において，岩盤にひすみエネルギが蓄積し， 岩盤内の断層が破断限界に達すると断層が破壊し，ひず みエネルギが岩盤内に解放され，振動として岩盤内を伝 播する。

2）建物直下の岩盤に到達した実体波としての地震動は 地表付近で増幅されて地表面に到達する。また，地表面 の地震動は, 地表面付近を水平に伝播する表面波を含ん でいる。

岩盤を伝播する地震動のフーリエ加速度振幅スペクト ルは，限界周期 $T_{c}$ より小さい周期範囲ではほぼ一定の 振幅を示すこと，および，地震のマグニチュードが増大 すると $T_{c}$ も大きくなることが明らかとなっている21,3)。

岩盤の地震動の地表面への増幅特性は波動の 1 次元重 複反射理論によってその大要が把握できることが明らか にされている(4) 。

また，地表面で得られた地震動から地盤の増幅特性を 消去して得られる基盤における地震動の速度応答スペク トルも周期に鈍感な平坦な形状を有することも明らかに されている”。

本論文では，まず，地震基盤における地震動を設定し， これに基づいて岩盤・地盤における実体波の増幅特性を 明らかにする。次いで，過去に記録された強震記録を参

\footnotetext{
* 東京大学 
Table 1 Referred Seismic Records

\begin{tabular}{|c|c|c|c|c|c|c|}
\hline $\begin{array}{l}\text { Name of } \\
\text { Earthquake } \\
\text { (Date) }\end{array}$ & Site of Record & Magnitude & $\begin{array}{l}\text { Epicentral } \\
\text { Distance } \\
(\mathrm{km})\end{array}$ & $\begin{array}{r}\text { Maximum } \\
\text { (cm } \\
\text { Horizonta }\end{array}$ & $\begin{array}{l}\text { lue of } \mathrm{V}_{\mathrm{E}} \\
\text { c) } \\
\text { Vertical }\end{array}$ & Substructure \\
\hline $\begin{array}{l}\text { Imperial Valley } \\
\text { (May } 18,1940 \text { ) }\end{array}$ & El Centro & 6.3 & 25 & 162.5 & 28.8 & Soil \\
\hline $\begin{array}{l}\text { Kem County } \\
\text { (July 21, 1952) }\end{array}$ & Taft & 7.4 & 43 & 101.5 & 43.7 & Soil \\
\hline $\begin{array}{l}\text { Tokachi-oki } \\
\text { (May 16, 1968) }\end{array}$ & Hachinohe & 7.9 & 180 & 222.6 & 78.0 & Soil \\
\hline \multirow{2}{*}{$\begin{array}{c}\text { Michoacan } \\
\text { (Sept 19, 1985) }\end{array}$} & La Union & \multirow{2}{*}{8.1} & 35 & 105.0 & 47.0 & Rock \\
\hline & Mexico City & & 350 & 74.0 & 52.0 & Rock \\
\hline
\end{tabular}

照して, 設計用地震動のエネルギスペクトルを求める。 参照した強地震動記録は Table 1 に示すものである。 なお，本論文では特にことわらない限り，h=0.1の工 ネルギスペクトルをエネルギスペクトルと呼ぶ。

\section{2. 岩盤・地盤における地震動の増幅}

\section{1 地震基盤における地震動}

観测された地震動は多少とも岩盤・地盤における増幅 の影響を受けているが，その内でも増幅の影響が少ない とされる Michoacan 地震の La Union における岩盤上 の記録波のエネルギスペクトルを Fig.1(a) に示す。 $V_{E}$ は诚衰 $10 \%$ ，周期 $T$ なる弾性系へのエネルギ入力 の速度換算值である。水平動に対する $V_{E}$ は次式による ものである。

$$
V_{E}=\sqrt{\frac{2\left(E_{E w}+E_{N S}\right)}{M}}
$$

ここで, $E_{E W}: E W$ 方向水平動による総エネルギ入力 $E_{N S}: N S$ 方向水平動による総エネルギ入力

一般に，上下動は水平動に比べて岩盤・地盤の増幅を 受けにくい。図中に示されるように，上下動のエネルギ スペクトルは $T$ に関する変化がなく平坦である。

Fig. 1(b) に示すものは，同一地震における震源から $350 \mathrm{~km}$ 離れた Mexico city の岩盤上の記録波のエネル ギスペクトルである。上下動のエネルギスペクトルは短

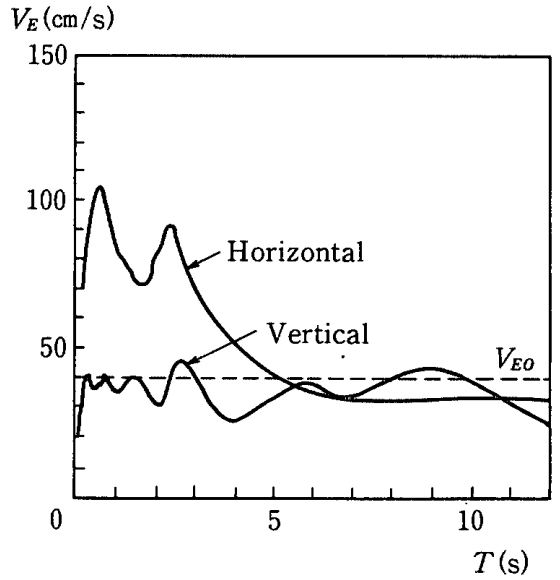

(a) La Union

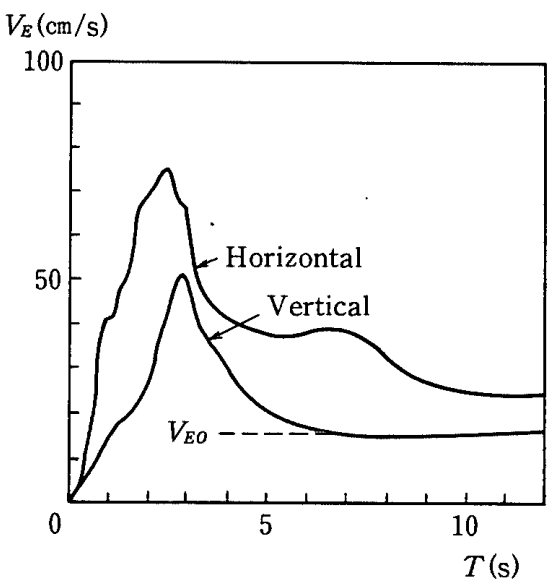

(b) Mexico City

Fig. 1 Energy Spectra for Records in Michoacan Earthquake

周期領域ではかなりの増幅を受けているが，長周期領域 では平坦である。

Fig. 2 には，土質地盤上の記録波のエネルギスペクト ルを示す。土質地盤上においても上下動のエネルギスペ

クトルは長周期領域で平坦な形状を持っている。

震源モデルに基づくフーリエ加速度振幅スペクトルも その形態は $T>T_{c}$ の領域で平坦とされており，地震基 盤におけるエネルギスペクトルの形態として, Fig. 3 に

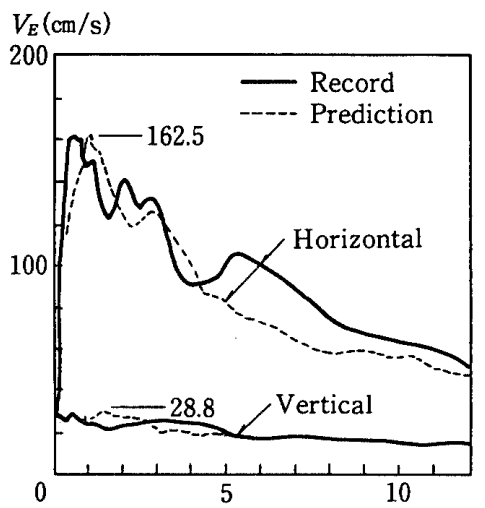

(a) El Centro

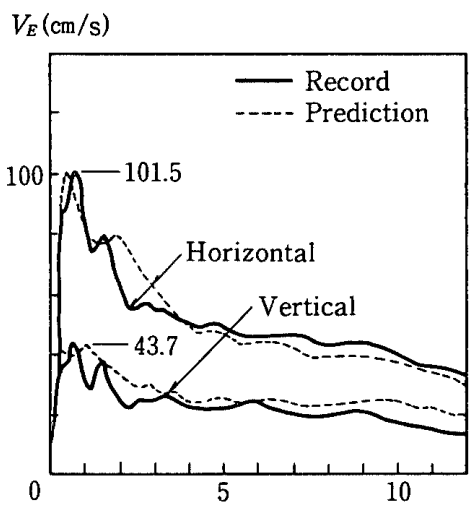

(b) Taft

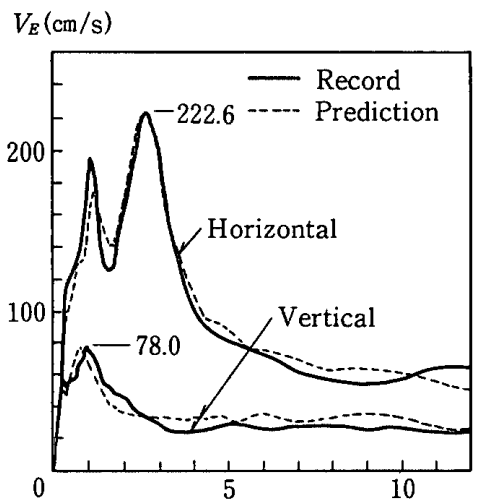

(c) Hachinohe

Fig. 2 Energy Spectra on Soil Surface 


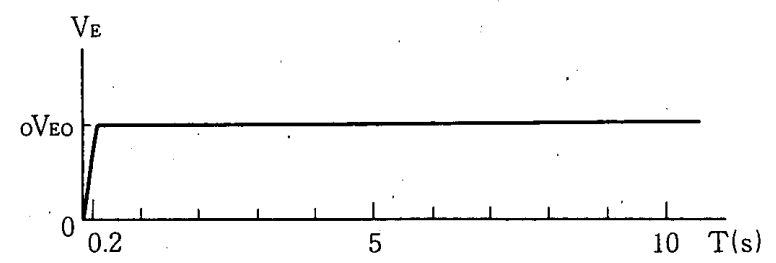

Fig. 3 Energy Spectrum for Ground Motions in Base Rock

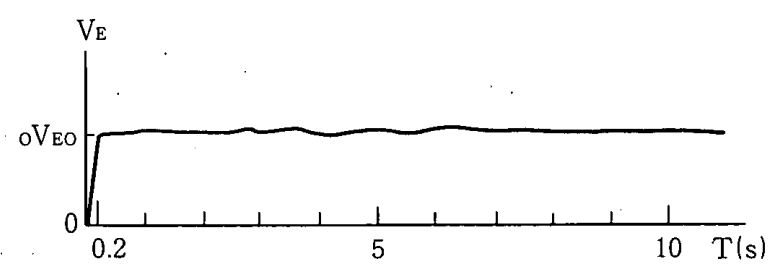

Fig. 4 Energy Spectrum of A Synthetic Ground Motion

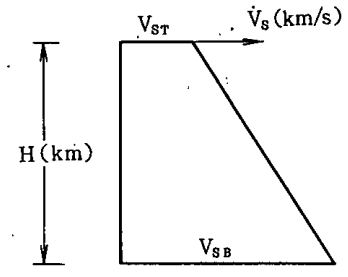

(a) Bedrock

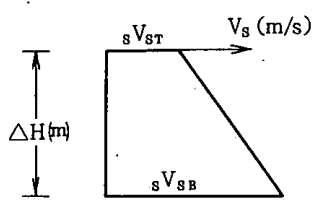

(b) Surface Soil
Fig. 5 Distribution of $V_{s}$ in Substructure

示すものを仮定する。ここで，地震基盤として $V_{s}$ が 3 $\mathrm{km} / \mathrm{s}$ 程度の硬岩層を考えている ${ }^{3)}$ 。また， $T_{C}$ の下限值 として $T_{C}=0.2 \mathrm{~s}$ を設定した。

\section{2 人工地震波による地震動の増幅解析}

地震基盤における地震動を模擬した人工地震波を作成 し, これを岩盤・地盤から成る地層構造底部に入力し， 岩盤表面および地表面における地震動を 1 次元波動伝播 理論により求める。得られた地震動のエネルギスペクト ルを比較することにより岩盤・地盤の振動増幅特性を求 める。

\subsection{1 人工地震波}

Fig. 3 に示されるエネルギスペクトルを有する人工地 震波 $\ddot{z}(t)$ を作成する。人工地震波は次式で表現される。

$$
\ddot{z}_{0}(t)=B(t) \sum_{k=1}^{n} A_{k} \cos \left(\frac{2 \pi}{T_{k}} t+\phi_{k}\right)
$$

ここで, $B(t)$ : 振幅の包絡関数 ${ }^{81}$

$$
\begin{aligned}
A_{k} & : \text { 振動成分の振幅 } \\
T_{k} & : \text { 振動成分の周期 } \\
\phi_{k} & : \text { 振動成分の位相角 } \\
t & : \text { 時間 }
\end{aligned}
$$

人工地震波の継続時間は 50 秒であり, 位相角は $0 \sim 2 \pi$ 間の一様乱数とした。 $T_{k}$ としては $0.05 \mathrm{~s} \leq T_{k} \leq 50 \mathrm{~s}$ の 範囲の 62 個を採り， $A_{k}$ は試行錯誤法により求めた。得 られた人工地震波のエネルギスペクトルを Fig. 4 に示 す。人工地震波は一波を用いたが, 岩盤, 地盤表面での エネルギスペクトルは, 地震波が目標エネルギスペクト

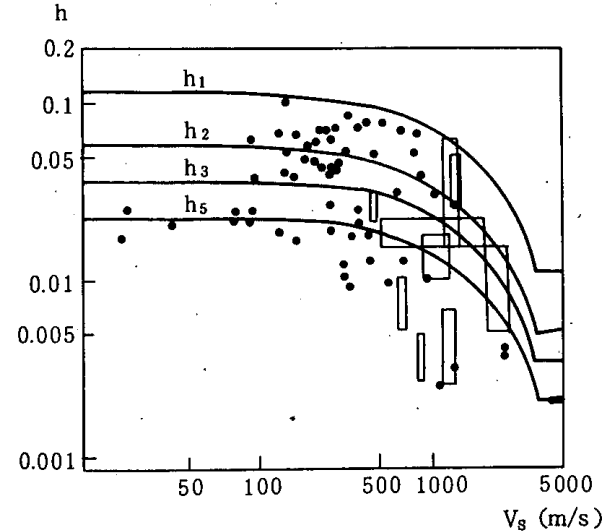

Fig. 6 Damping Constant in Ground (from Fig. 4.35 in Ref. (9))

ルに適合するものである限り, 地震波の違いによる影響 をほとんど受けないことは確かめてある。

\subsection{2 岩盤・地盤の構成}

岩盤・地盤としてはFig. 5 に示す成層構造を設定す る。すなわち, 岩盤は深さが $H(\mathrm{~km})$ で表面の S 波速 度が $V_{S T}(\mathrm{~km} / \mathrm{s})$ 基部の $\mathrm{S}$ 波速度が $V_{S B}(\mathrm{~km} / \mathrm{s})$ である。 表層地盤は深さが $\Delta H(\mathrm{~m})$ で; 表面の $\mathrm{S}$ 波速度が ${ }_{s} V_{S T}$ $(\mathrm{m} / \mathrm{s})$ ，基部の $\mathrm{S}$ 波速度 ${ }_{s} V_{S B}(\mathrm{~m} / \mathrm{s})$ である。

岩盤・地盤の物性值は次のように設定した ${ }^{9)}$ 。

密度 $\gamma=1.5+0.0004 V_{s}\left(\mathrm{t} / \mathrm{m}^{3}\right)$

世ん断弾性係数 $G=\frac{\gamma V_{s}^{2}}{g}\left(\mathrm{t} / \mathrm{m}^{2}\right)$

P波速度 $V_{\rho}=1000+1.4 V_{s}(\mathrm{~m} / \mathrm{s})$

減衰定数 $h_{1}=-\frac{V_{s}}{30000}+0.11$, ただし, $h_{1} \geq 0.01$

ここで $V_{s}$ の単位は $\mathrm{m} / \mathrm{s}, g:$ 重力加速度 $=9.8 \mathrm{~m} / \mathrm{s}^{2}$ 減衰定数の基準值 $h_{1}$ は岩盤 - 地盤の減衰定数の上限值 に近い值である。 $h_{1}$ を基準として，他の 3 通りの減衰 定数を次のように設定した。

$$
h_{2}=\frac{h_{1}}{2}, \quad h_{3}=\frac{h_{1}}{3}, \quad h_{5}=\frac{h_{1}}{5}
$$

$h_{1} \sim h_{5}$ は既往の調查結果 ${ }^{9)}$ と比較して Fig. 6 に示されて いる。

\section{2 .3 増幅率}

人工地震波を岩盤基部に入力し, 次の 2 種類の応答波 を求めた。

1）表層地盤がない場合の岩盤表層の加速度応答波

2）岩盤・地盤系の表層地盤表面上の加速度応答波 無減衰の均質岩盤の基部に地震動を入力した場合，岩盤 の表面の地震動は 2 倍に増幅される。したがって,岩盤・ 地盤の応答増幅は, 基盤入力加速度記録の振幅を 2 倍し た地震波に対して評価する。すなわち, 次式により応答 増幅を評価する。

$$
f_{R}=\frac{{ }_{R} V_{E}}{V_{E 0}}, \quad f_{S}=\frac{{ }_{s} V_{E}}{V_{E 0}}
$$




\section{ここで, $f_{R}$ ：岩盤による増幅率}

\section{$f_{S}$ : 地盤による増幅率}

${ }_{R} V_{E}:$ 岩盤表面の波形のエネルギスペクトル ${ }_{s} V_{E}$ : 地盤表面の波形のエネルギスペクトル $V_{E 0}:$ 基盤入力波のエネルギスペクトルの平坦 部の値 。 $V_{E_{0}}$ の 2 倍

水平地震動の増幅特性を求める際には一次元せん断波重 複反射理論を用い, 上下地震動の增幅特性を求める際に は一次元 $\mathrm{P}$ 波重複反射理論を用いた。

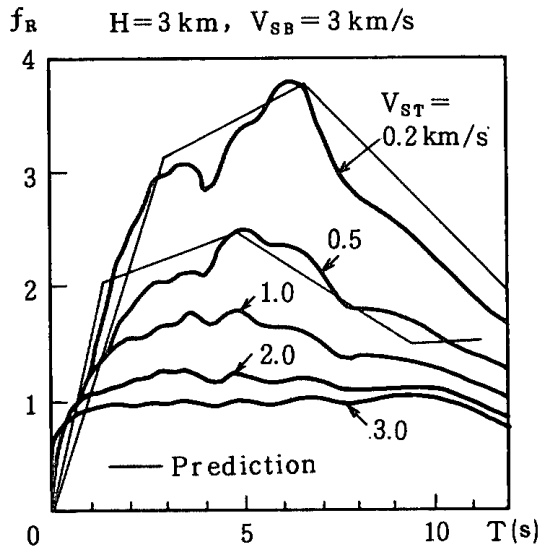

(a)

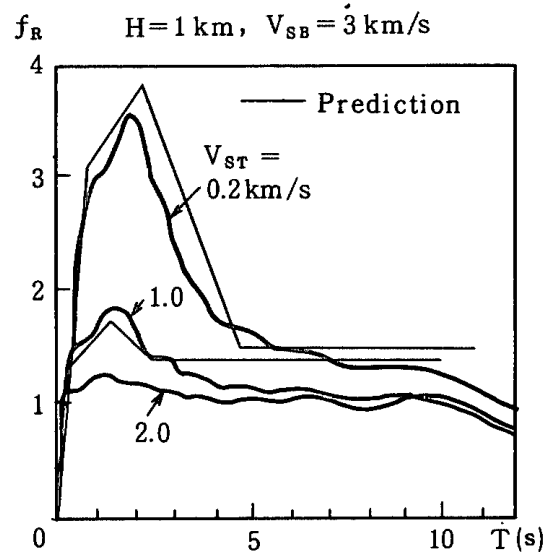

(b)

Fig. 7 Energy Spectra of Horizontal Ground Motion on Rock Surface

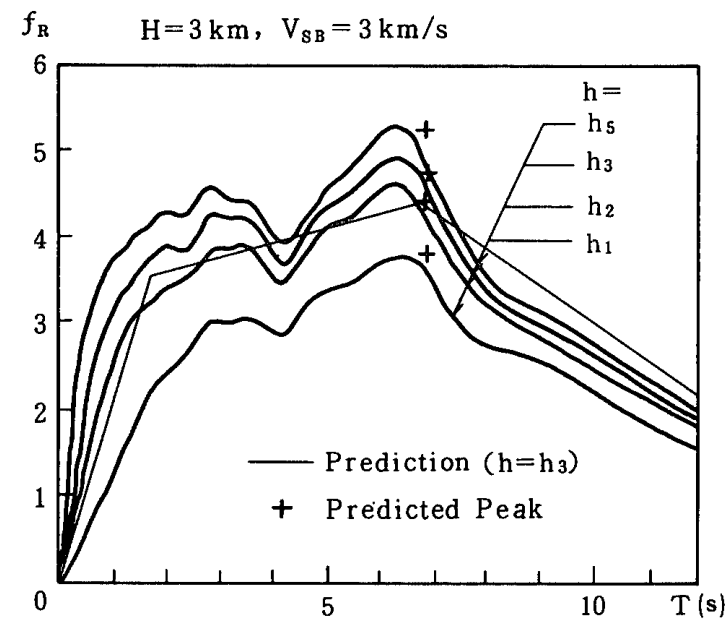

Fig. 8 Effect of Damping

\section{3 岩盤・地盤の増幅特性}

Fig. 7 には種々の岩盤上の水平地震動の増幅率と $T$ との関係，すなわち $V_{E 0}$ で無次元化されたエネルギスペ クトルを示す。岩盤構成は, $H, V_{S T}, V_{S B}$ によって示さ れている。 $H, V_{s T}, V_{S B}$ の単位は 2.2 .2 に示されている。 岩盤の增幅率を支配するものは岩盤表面と岩盤基部の $V_{S}$ の比率 $V_{S T} / V_{S B}$ である。岩盤の卓越周期は $V_{S T} / V_{S B}$ および岩盤深さ $H$ に支配される。

Fig. 8 には減衰定数の変化による増幅特性の変化を示 す。減衰定数の岩盤の増幅特性に及ぼす影響はそれほど 顕著ではない。

Fig. 9 は岩盤上の鉛直地震動のエネルギスペクトルを 示す。P波速度がS 波速度に比べて大きいことから，岩 盤の卓越周期は水平地震動の場合に比べて短くなってい る。

Fig. 10 には地盤表面上の水平地震動の無次元化され たエネルギスペクトル（エネルギスペクトルの増幅率） を示す。地盤構成は， $\Delta H,{ }_{s} V_{s T},{ }_{s} V_{S B}$ によって示され ている。岩盤構成は $R-H-V_{S T}-V_{S B}$ によって示されてい る。 $R$ は岩盤構成であることを示す。 $\Delta H,{ }_{s} V_{s T},{ }_{s} V_{s B}$ の単位は 2.2 .2 に示されている。増幅率は地盤表面と岩 盤表面の $V_{s}$ の比 ${ }_{s} V_{s T} / V_{s T}$ に支配される。

Fig. 11 には地盤表面上の鉛直地震動の無次元化され
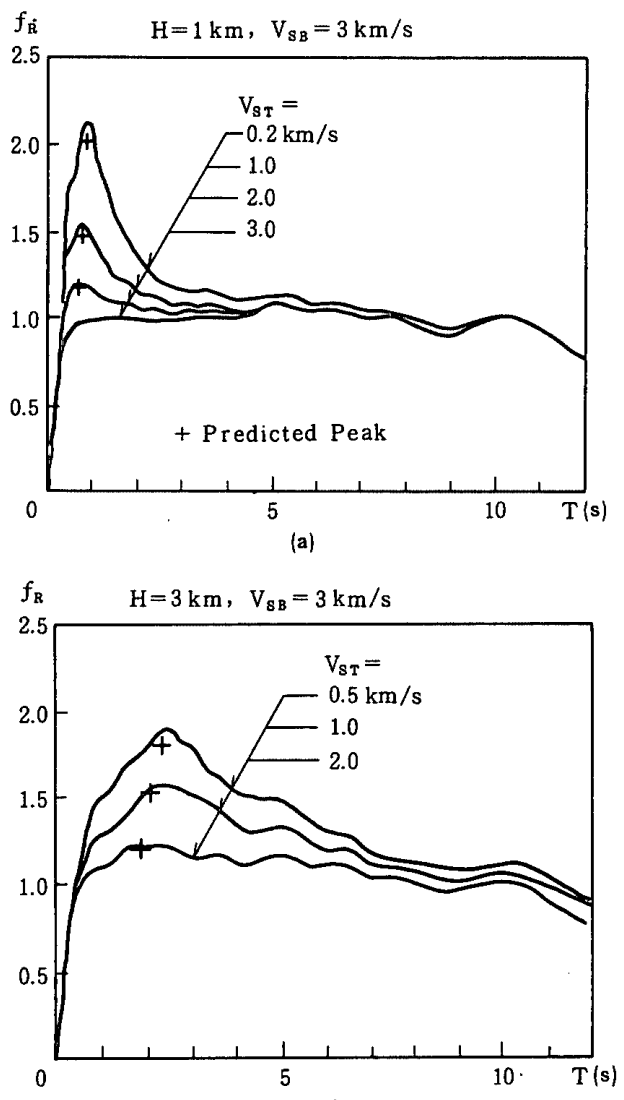

(b)

Fig. 9 Energy Spectra of Vertical Ground Motion on Rock Surface 


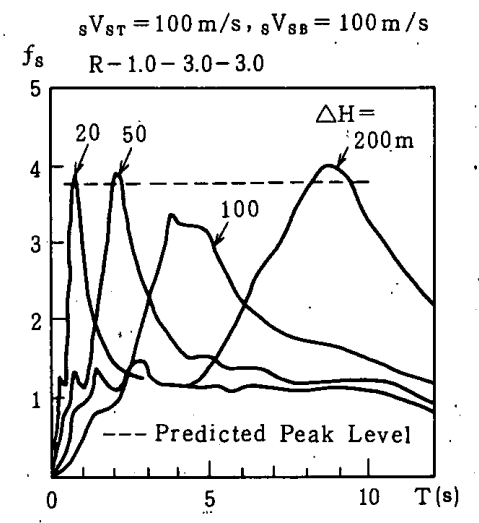

(a) $\mathrm{H}=1 \mathrm{~km}, \mathrm{~h}=\mathrm{h}_{1}$

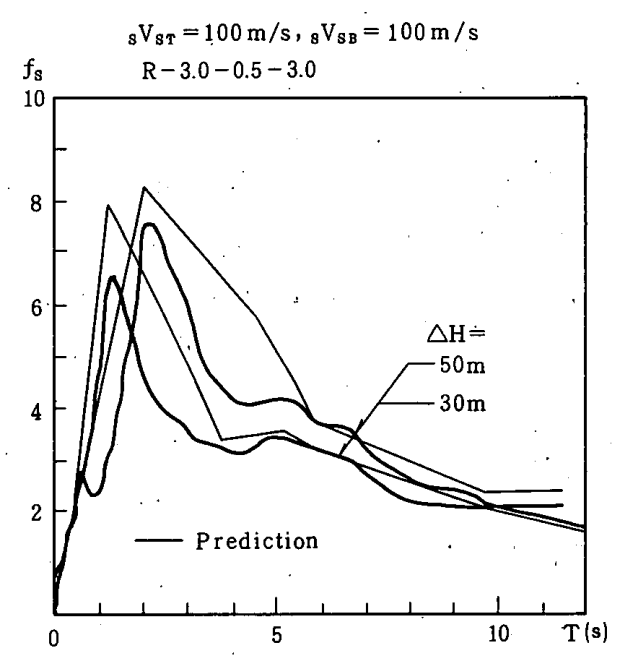

(b) $\mathrm{H}=3 \mathrm{~km}, \mathrm{~h}=\mathrm{h}_{2}$

Fig. 10 Energy Spectra of Horizontal Ground Motion on Soil Surface

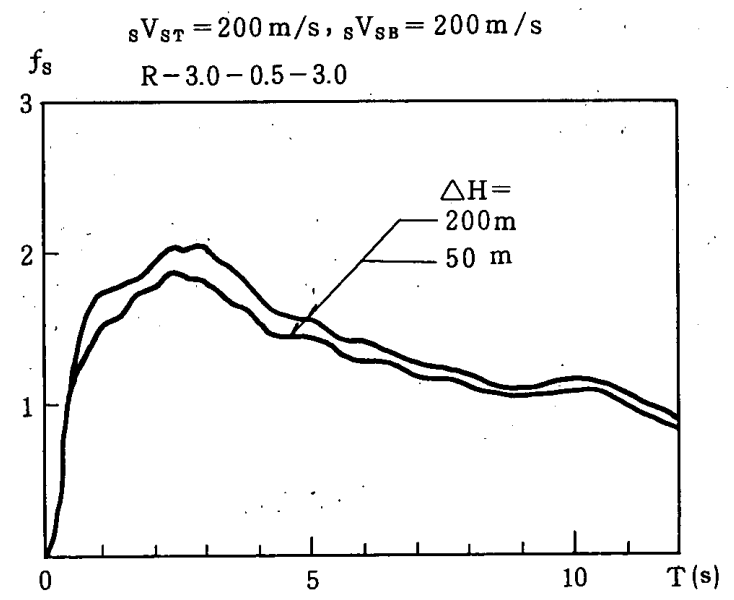

Fig. 11 Energy Spectra of Vertical Ground Motion on Soil Surface

たエネルギスペクトルを示す。P波速度は表層地盤にお いてもあまり変化しないことから, 岩盤においてある程 度の増幅を受ける場合には, 表層地盤における増幅は相 対的に小さくなる。なお，岩盤表面のエネルギスペクト ルは $\Delta H=50 \mathrm{~m}$ の場合とほとんど等しい。

2.4 増幅率の簡易評価式

岩盤地盤の地震動の増幅特性を把握するために, 一連

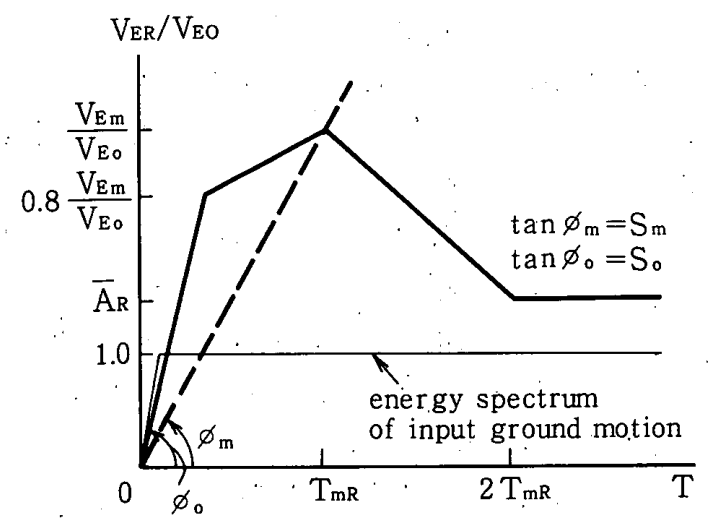

Fig. 12 Energy Spectrum on Rock Surface

の応答解析結果に基づき, 岩盤表面および地盤表面の地 震動の無次元化されたエネルギスペクトルの簡易評価式 を求めた。結果は次のように要約される。

\section{4 .1 岩盤表面上の無次元化エネルギスペクトル}

岩盤表面のエネルギスペクトル $\left(V_{E R}-T\right.$ 関係) は Fig. 12 に示す形態を持つ。すなわち，岩盤の卓越周期 $T_{m R}$ でエネルギスペクトルは極值 $V_{E m}$ を採る。 $T>2$ $T_{m R}$ では，エネルギスペクトルの応答倍率は一定值 $\bar{A}_{R}$ を採る。短周期領域は原点を通る線分で与えられ，その 勾配 $S_{0}$ は極大点 $\left(T_{m R}, V_{E m}\right)$ の割線勾配 $S_{m}$ と対応づけ られる。短周期領域の限界点のエネルギスペクトル值 $\dot{V}_{E R 0}$ の值は $0.8 V_{E m}$ で近似できる。エネルギスペクトル を規定する諸量を支配パラメータの単純な結合則として 求めた結果, 次の諸式が得られた。

1）水平地震動の場合

$$
\left.\begin{array}{l}
\frac{V_{E m}}{V_{E 0}}=\left(\frac{V_{S B}}{V_{S T}}\right)^{0.5}\left(\frac{h_{1}}{h}\right)^{0.2} ; \\
T_{m R}=\left(0.5+0.3 \frac{V_{S T}}{V_{S B}}\right) T_{0} \\
T_{0}=\frac{4 H}{V_{S B}}\left(\frac{V_{S B}}{V_{S T}}\right)^{0.44} \\
\bar{A}_{R}=\left\{1.5-0.5\left(\frac{V_{S T}}{V_{S B}}\right)\right\}\left(\frac{h_{1}}{h}\right)^{0.15} \\
\frac{S_{0}}{S_{m}}=7\left(\frac{V_{E 0}}{V_{E m}}\right)\left(\frac{h_{1}}{h}\right)
\end{array}\right\}
$$

2) 鉛直地震動の場合

$$
\left.\begin{array}{l}
\frac{V_{E m}}{V_{E 0}}=\left(\frac{V_{P B}}{V_{P T}}\right)^{0.5}\left(\frac{h_{1}}{h}\right)^{0.2} \\
T_{m}=\left(0.5+0.3 \frac{V_{P T}}{V_{P B}}\right) T_{0} \\
T_{0}=\left(\frac{4 H}{V_{P B}}\right)\left(\frac{V_{P B}}{V_{P T}}\right)^{0.44} \\
\bar{A}_{R}=\left\{1.5-0.5\left(\frac{V_{P T}}{V_{P B}}\right)\right\}\left(\frac{h_{1}}{h}\right)^{0.15} \\
\frac{S_{0}}{S_{m}}=7\left(\frac{V_{E 0}}{V_{E m}}\right)\left(\frac{h_{1}}{h}\right)
\end{array}\right\}
$$




\section{$V_{P T}$ : 岩盤表面における $\mathrm{P}$ 波速度}

\section{4 .2 地盤表面上の無次元化エネルギスペクトル}

岩盤上のエネルギスペクトルに基づき，地盤表面上の 水平地震動のエネルギスペクトル $\left(V_{E S}-T\right.$ 関係) は Fig. 13 に示すように作図することができる。エネルギ スペクトルは地盤の卓越周期 $T_{m s}$ で極值 $a_{m s} V_{E R 1}$ を採 る。 $T>3 T_{m s}$ では増幅率は一定值 $a_{s 2}$ である。 $T_{m s}<T$ $<3 T_{m s}$ における増幅率は $T_{m s}$ における増幅率 $a_{m s}$ 之 $a_{s 2}$ を線形補間した値となる。

エネルギスペクトルを規定する諸量は次のように与えら れる。

1) $a_{m s} V_{E R 1}>V_{E R 0}$ の場合

i ) $T \leq T_{m s}$ の場合

a) $\frac{V_{E R 0}}{T_{R 0}}<\frac{a_{m S} V_{E R 1}}{T_{m S}}$ の場合

$\mathrm{O}-\mathrm{A}^{\prime}$ 点を結ぶ線分を採る。

b) $\frac{V_{E R 0}}{T_{R 0}} \geq \frac{a_{m s} V_{E R 1}}{T_{m S}}$ の場合

1) $\frac{V_{E m}}{T_{m R}}<\frac{a_{m s} V_{E R 1}}{T_{m s}}$ の場合

$\mathrm{O}-\mathrm{A}-\mathrm{A}^{\prime}$ 点を結ぶ線分を採る。

) $\frac{V_{E m}}{T_{m R}} \geq \frac{a_{m s} V_{E R 1}}{T_{m s}}$ の場合

O-A-B-A'点を結ぶ線分を採る。

ii) $T_{m s}<T<3 T_{m s}$ の場合

$V_{E S}=a_{S 1} V_{E R}$

iii) $3 T_{m s}<T$ の場合

$V_{E S}=a_{S 2} V_{E R}$

2) $a_{m s} V_{E R 1} \leq V_{E R 0}$ の場合

表層地盤による増幅は無視できる。

ここで, $T_{m s}$ ：表層地盤の卓越周期

$V_{E R 1}: T=T_{m S}$ における岩盤表面上のエネル ギスペクトル值

$T_{R 0}: V_{E R 0}$ に対応する周期

$$
\begin{aligned}
& T_{m s}=\frac{4 \Delta H}{{ }_{s} V_{S B}}\left(\frac{{ }_{s} V_{S B}}{{ }_{s} V_{S T}}\right)^{0.44}\left\{0.5+0.5\left(\frac{{ }_{s} V_{S T}}{{ }_{s} V_{S B}}\right)^{0.4}\right\} \\
& a_{m s}=5\left\{1-\left(\frac{s V_{s T}}{V_{s T}}\right)^{0.4}\right\}\left(\frac{h_{1}}{h}\right)^{0.5} \\
& \text { 但し, } \frac{{ }^{s} V_{s T}}{V_{s T}}>0.5 \text { の場合, } \frac{{ }_{s} V_{s T}}{V_{s T}} \text { を } 0.5 \text { とする。 } \\
& a_{S 2}=\left\{1+0.8\left(\frac{\Delta H}{s V_{S T}}\right)^{1.5}\right\}\left(\frac{h_{1}}{h}\right)^{0.15} \\
& a_{s 1}=\frac{3 a_{m s}-a_{s 2}}{2}+\left(\frac{a_{s 2}-a_{m s}}{2}\right)\left(\frac{T}{T_{m s}}\right)
\end{aligned}
$$

Fig. 7〜11には (5)〜（ 7$)$ 式による予測值が示され ている。鉛直地震動のエネルギスペクトルも同様であっ て，（7）式中のせん断波速度をP波速度に置き換える ことにより増幅率, 卓越周期が評価できる。

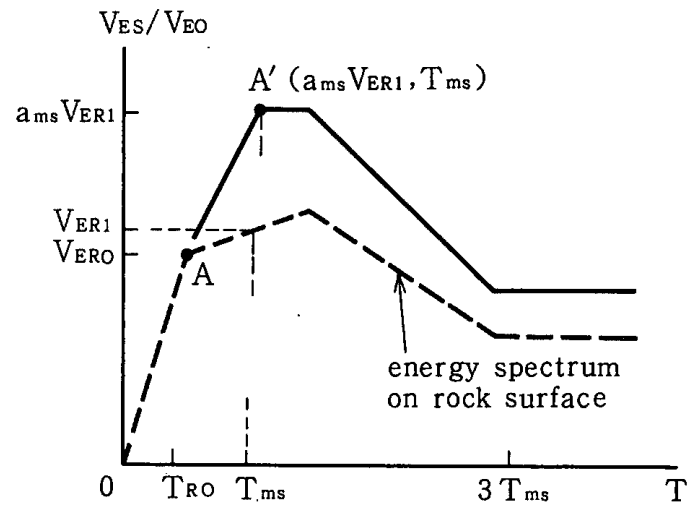

Fig. 13 Energy Spectrum on Soil Surface

\section{3. 設計用エネルギスペクトル}

\section{1 基盤における地震動の強さ}

表層地盤の増幅を受ける前の基盤における地震動の強 さに関しては, 基礎の梁さが $3 \mathrm{~km}$ 程度に達することか ら実測例がほとんどなく，その推定が難しい。また，設 計で対象とすべきマグニチュード 8 釉の地震記録も極め て少ない。過去における観測記録を統計処理して地震動 の強さを一般的に表現しようとする場合, 記録数を増せ ば，中小地震記録を含めざるを得ず，地震動を規定する 諸量の相対的関係を得られるとしても，大地震の奏像を 的確にとらえることは困難となる。

本論文では, Table 1 に示す強地震記録のみを用いて, 岩盤・地盤の増幅を消去して得られる基盤における地震 動強さを求め，それに基づいて設計用エネルギスペクト ルを提案する。

基盤におりる開放基盤上の地震動のエネルギスペクト ルの形態として Fig. 14 に示すものを仮定する。した がって, 求めるべきものはエネルギスペクトルのレベル $V_{E 0}$ である。 $V_{E 0}$ は開放基盤上における地震動の最大速 度 $V$ と対応づけることができる ${ }^{10)}$ 。文献 10）によれば, 地震動のスペクトル強度と地震動の最大速度との関係は 次のように求められている。

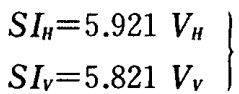

ここで, $S I_{H}, S I_{V}$ : 水平動および上下動のスペクトル 強度

$$
S I=\int_{0.1}^{2.5} S_{v, h=0} d T
$$

$S_{v, h=0}:$ 無娍衰系の速度応答スペクトル $V_{H}, V_{V}:$ 水平動および上下動の最大速度 $S_{v, h=0}$ は無減衰系のエネルギスペクトル $V_{E, h=0}$ とほぼー 致する ${ }^{1)} 。 V_{E, h=0}$ を平滑化したスペクトルが $V_{E, h=0.1}$ に対 応する。スペクトルを平滑化しても積分值は変わらない。 したがって,$h=0.1$ のエネルギスペクトルを Fig. 14 のように仮定した場合, $S I$ と $V_{E}$ とは次式で対忘つけ られる。 


$$
S I=2.375 V_{E O}
$$

(8)，（9）式より，エネルギスペクトルのレベルを地 動の最大速度は次式のように対応づけられる。

$$
\left.\begin{array}{l}
{ }_{H} V_{E 0}=2.5 V_{H} \\
{ }_{V} V_{E 0}=2.5 V_{Y}
\end{array}\right\}
$$

ここで, ${ }_{H} V_{E 0}:$ 水平地震動のエネルギスペクトルのレ ベル

${ }_{V} V_{E 0}:$ 鉛直地震動のエネルギスペクトルのレ ベル

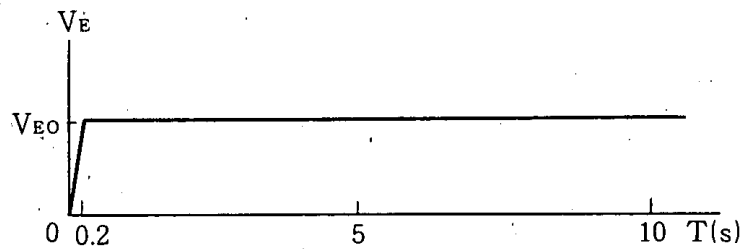

Fig. 14 Energy Spectrum on Base Rock
Table 1 に示す El Centro 記録, Taft 記録，八戸記録

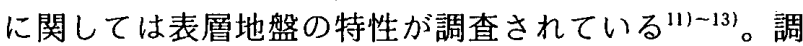
查結果の $V_{s}$ 分布と Fig. 5 に従って単純化した $V_{s}$ 分布 をFig. 15 に示す。いずれの地点においても，岩盤表面 付近の $V_{S}$ 值を除けば岩盤の特性は明らかでない。 $V_{S}$ が $3 \mathrm{~km} / \mathrm{s}$ 程度に達する深さを基盤深さと考え，エネル ギスペクトルの卓越周期を参考にして岩盤深さ $H$ を設 定して得られた岩盤の $V_{s}$ 分布が Fig. 15 中に示されて いる。

Fig. 15 に示される単純化された $V_{s}$ 分布を用い，重 複反射理論により求めた地表面上のエネルギスペクトル がFig.16 に示されている。Fig. 2 中には, Fig. 16 に示 すエネルギスペクトルを最大值を Fig. 2 中の対応する エネルギスペクトルの最大值に一致させて予測值として 示してある。なお，解析に用いた減衰定数は $h_{2}$ である。

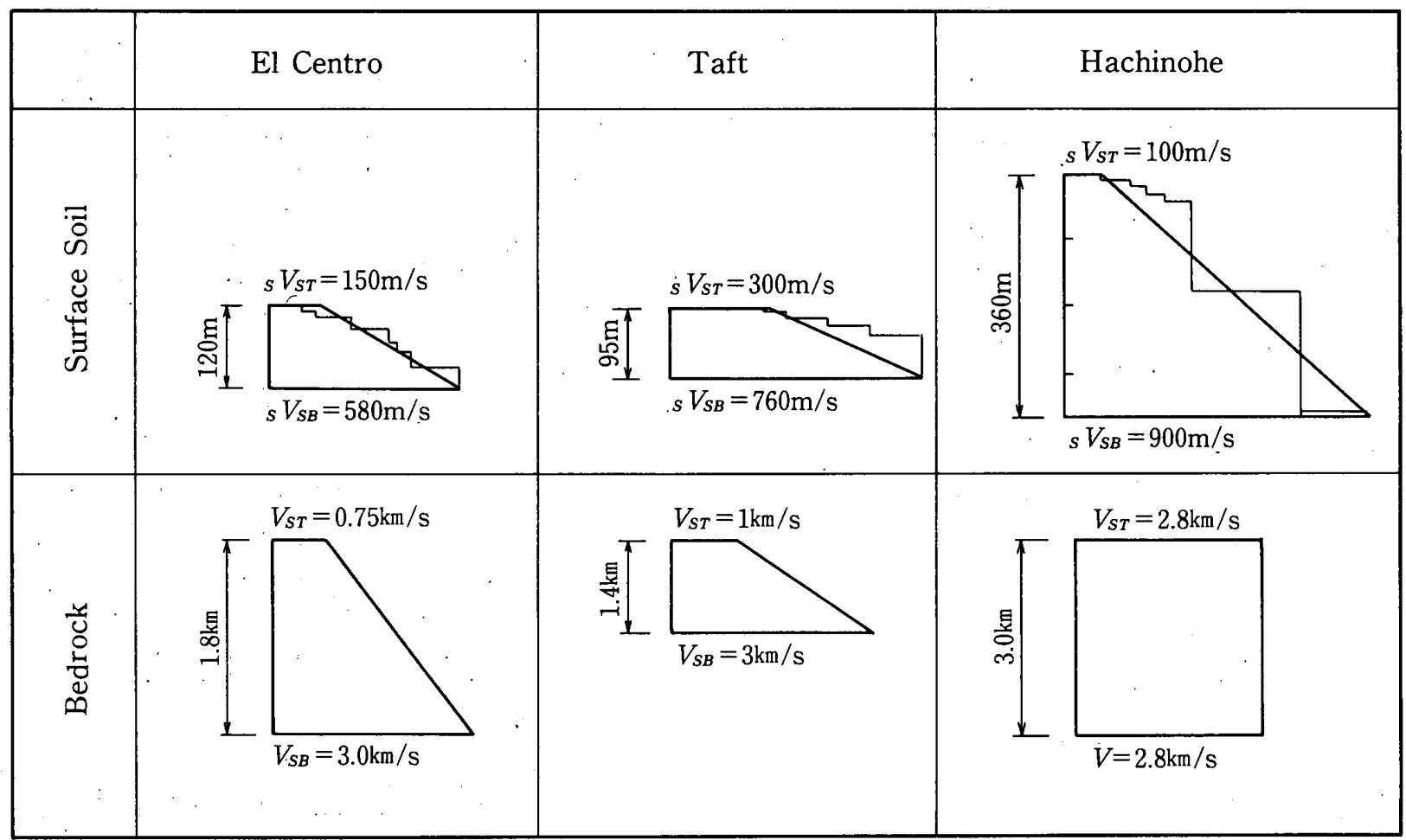

Fig. 15 Assumed $V_{s}$-Profile in Sites of Strong Record

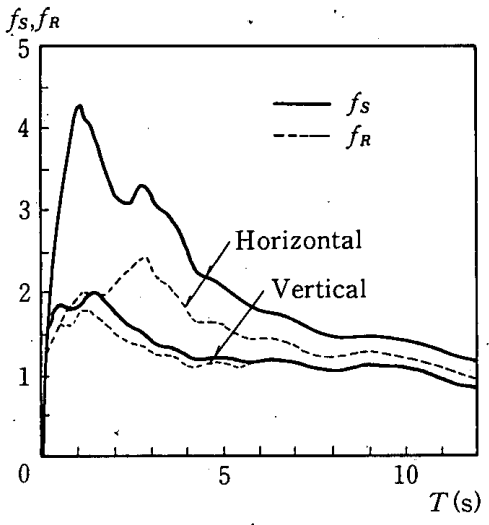

(a) El Centro

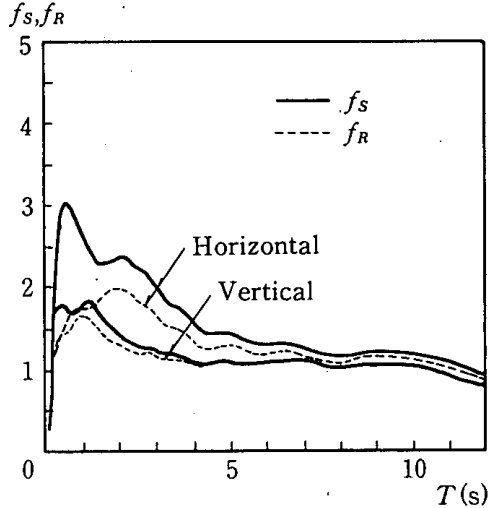

(b) Taft

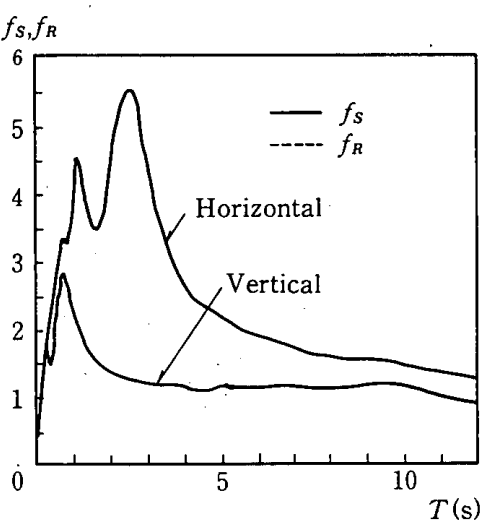

(c) Hachinohe

Fig. 16 Calculated Energy Spectra 
Fig. 2 に示されるように，スペクトルの形状は 1 次元波 動伝播理論により予測可能であると言える。

Fig. 2 に示すエネルギスペクトルの最大值を Fig. 16 に示す増幅率の最大值で除せば, Table 2 に示すように, 基盤におけるエネルギスペクトルのレベル $V_{E 0}$ を求める ことができる。さらに（10）式を用いれば，基盤におけ る最大速度を求めることができる。

既に地動の最大速度に関しては多くの研究があ $\eta^{14) ~ 16)}$ ，水平地動の最大速度に対する鉛直地動の最大 速度の比に関して，おおむね次の関係が成立すると言わ れている。

$$
0.3 \leq \frac{V_{V}}{V_{H}} \leq 1.0
$$

Table 2 に示す $V_{v}$ と $V_{H}$ の比率を参照して，次の值を設 定する。

$$
\frac{V_{v}}{V_{H}}=0.7
$$

Fig. 17 はマグニチュード 8 級の大地震の基盤におけ る上下動の最大値を震源距離 $X$ との関係で描いたもの である。いずれの值も基盤におけるエネルギスペクトル のレベル $V_{E 0}$ より $(10)$ 式を用いて得たものである。

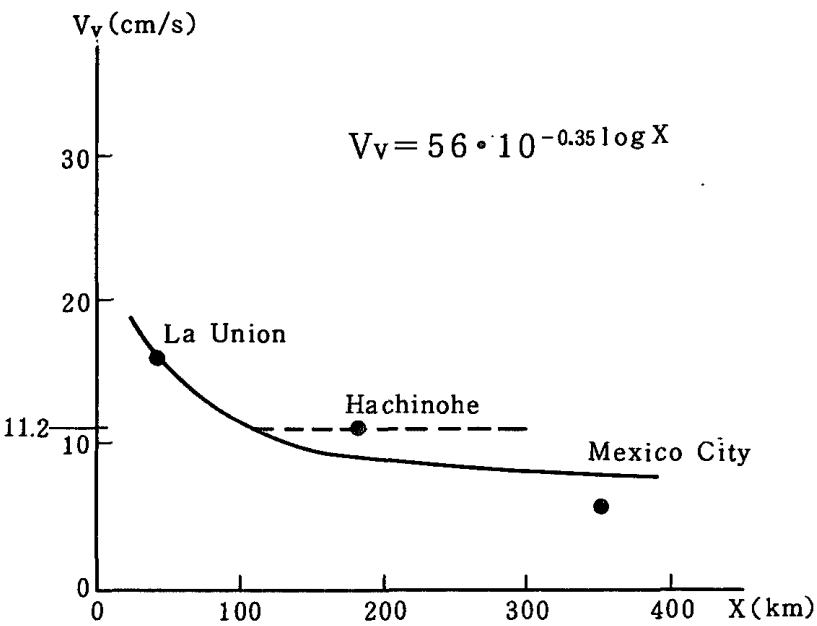

Fig. 17 Maximum Vertical Velocity in Base Rock

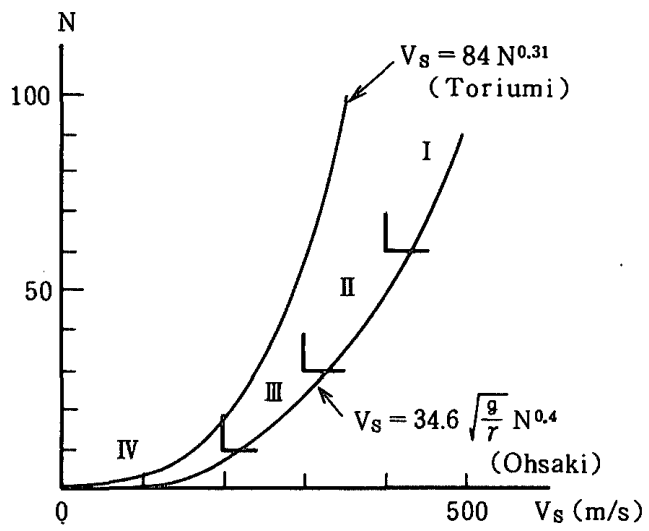

Fig. $18 N$-Value and $V_{s}$
La Union の記録については，Fig.1(a) に見られるよ うに地盤増幅の影響はないと考えられ，工ネルギスペク トルから $V_{E 0}$ は容易に読みとれる。Mexico city の記録 はFig.1(b)に示すエネルギスペクトルにおいて,岩盤・ 地盤の増幅の影響がないと考えられる $6 \mathrm{sec}<T<10$ $\sec$ の範囲の $V_{E}$ の值を $V_{E 0}$ としている。

Fig. 17 の $V_{V}-T$ 関係は次式で近似できる。

$$
V_{v}=56 \cdot 10^{-0.3510 g} x
$$

$V_{V}$ の代表值として $X=100 \mathrm{~km}$ における $V_{V}$ を（13）式 より求めると, $V_{V}=11.2 \mathrm{~cm} / \mathrm{s}$ を得る。この值は, Table 2 に示す強震記録の $V_{\boldsymbol{v}}$ の上限に位置する。そこ で，この值を設計用エネルギスペクトルを求める際の基 準值とする。(10)，(11）式より，設計用エネルギスペ クトルのレベル $V_{E 0}$ は Table 3 に示すように設定され

\begin{tabular}{|c|c|c|c|c|c|c|}
\hline & $\begin{array}{r}\text { El Cen } \\
\text { Horizontal }\end{array}$ & Vertical & $\begin{array}{r}\mathrm{Ta} \\
\text { Horizontal }\end{array}$ & Vertical & $\begin{array}{r}\text { Hachir } \\
\text { Horizontal }\end{array}$ & $\begin{array}{l}\text { ohe } \\
\text { Vertical }\end{array}$ \\
\hline $\begin{array}{l}\text { Maximum Value of } V_{B} \\
V_{\mathrm{E}}(\mathrm{cm} / \mathrm{s})\end{array}$ & 162.5 & 28.8 & 101.5 & 43.7 & 222.6 & 78.0 \\
\hline $\begin{array}{c}\text { Spectral Amplification } \\
V_{E m / V_{B O}}\end{array}$ & 4.30 & 2.06 & 3.06 & 1.81 & 5.55 & 2.77 \\
\hline $\begin{array}{l}\text { Level of VBo } \\
(\mathrm{cm} / \mathrm{s})\end{array}$ & 37.8 & 14.0 & 33.1 & 24.1 & 40.1 & 28.2 \\
\hline $\begin{array}{l}\text { Maximum Velocity } \\
\text { in Base Rock } \\
V_{m}\left(=V_{B O} / 2.5\right)\end{array}$ & 15.1 & 5.6 & 13.3 & 9.7 & 16.0 & 11.3 \\
\hline
\end{tabular}
る。

Table 2 Level of Seismic Motions in Base Rocks

Table 3 Ground Motion in Base Rock

\begin{tabular}{|c|c|c|c|c|c|c|c|}
\hline Subsoil Conditions & $\begin{array}{l}\mathrm{sVsT} \\
(\mathrm{m} / \mathrm{s})\end{array}$ & $\begin{array}{l}\mathrm{s} \mathrm{V}_{\mathrm{BT}} \\
(\mathrm{m} / \mathrm{s})\end{array}$ & $\begin{array}{l}\Delta \mathbf{H} \\
(\mathrm{m})\end{array}$ & $\begin{array}{c}\mathrm{Vs} \\
(\mathrm{km} / \mathrm{s})\end{array}$ & $\begin{array}{c}\mathrm{V}_{\mathrm{sB}} \\
(\mathrm{km} / \mathrm{s})\end{array}$ & $\underset{(\mathrm{km})}{\mathrm{H}}$ & N-Value \\
\hline I & 400 & 400 & \multirow{4}{*}{$\begin{array}{r}30 \\
\text { to } \\
100\end{array}$} & \multirow{4}{*}{$\begin{array}{c}0.5 \\
\text { to } \\
1.5\end{array}$} & \multirow{4}{*}{3.0} & \multirow{4}{*}{3.0} & $60 \leq N$ \\
\hline II & 300 & 300 & & & & & $30 \leq N \leq 60$ \\
\hline III & 200 & 200 & & & & & $10 \leq \mathrm{N} \leq 30$ \\
\hline IV & 100 & 100 & & & & & $N \leq 10$ \\
\hline
\end{tabular}

\begin{tabular}{|c|c|c|}
\cline { 2 - 3 } \multicolumn{1}{c|}{} & Horizontal & Vertical \\
\hline $\begin{array}{c}\text { Maximum Velocity } \\
V_{m}(\mathrm{~cm} / \mathrm{s})\end{array}$ & 16.0 & 11.2 \\
\hline $\begin{array}{c}\text { Energy Spectral Level } \\
V_{\text {Eo }}(\mathrm{cm} / \mathrm{s})\end{array}$ & 40.0 & 28.0 \\
\hline
\end{tabular}

Table 4 Standardization of Substructure

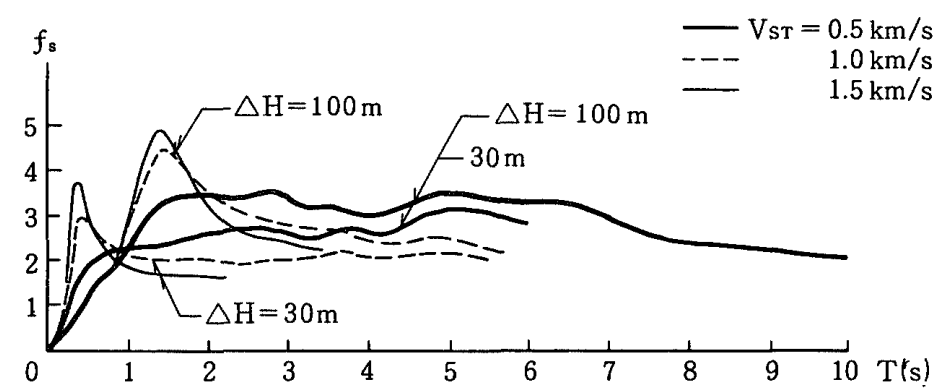

Fig. 19 Energy Spectra on the IInd Ground 


\section{2 設計用エネルギスペクトル}

地震動の増幅は地盤・岩盤の構成，すなわちせん断波 速度の分布によって異なる。増幅特性において支配的な 量は $V_{S T} / V_{S B},{ }_{s} V_{S T} / V_{S T}, \Delta H, H$ である。 $H$ は岩盤の 卓越周期を支配する。 $H$ については, 岩盤の増幅が広 い周期帯に及ぶように $H=3 \mathrm{~km}$ を設定値とする。 $\Delta H$

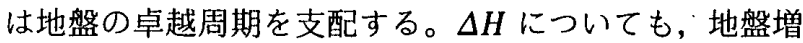
幅の影響範囲を広く考慮するために $\Delta H=30 \mathrm{~m} \sim 100 \mathrm{~m}$ の範用で設定する。 $V_{S T}, s V_{s T}$ に関しても，広い範囲の 值の変化を考虑して次の範囲の值を設定する。

\section{$0.5 \mathrm{~km} \leq V_{s r} \leq 1.5 \mathrm{~km}$ \\ $100 \mathrm{~m} \leq{ }_{S} V_{S T} \leq 400 \mathrm{~m}$}

以上の設定值に基づき, Table 4 に示す 4 種の地盤種別 を設定する。表中の $V_{S}$ の值は地盤種別ごとの最低值で ある。

せん断波速度と標準貫入試験による $N$ 值との関係は 多くの研究者により提案されている ${ }^{17), 18)}$ 。Fig.18には $N$ 值と $V_{S}$ との関係を示す。これ等の研究成果を参照し て, Table 4 中には $V_{s}$ の範囲と対応させておおよその $N$ 値の範囲を示している。なお，表中， ${ }_{s} V_{S T} /{ }_{s} V_{S B}$ は表 層地盤の増幅にほとんど影響を与えないので ${ }_{S} V_{S T}={ }_{S} V_{S B}$ としている。 $\Delta H$ は地盤の増幅率にほとんど影響を与え ず，地盤の卓越周期を支配する量であり， Table 4 中の 両端の值 $\Delta H=30 \mathrm{~m}, 100 \mathrm{~m}$ についてエネルギスペクト ルを求めた。 $V_{S T}$ については代表值として， $V_{S T}=0.5$ $\mathrm{km} / \mathrm{s}, 1.0 \mathrm{~km} / \mathrm{s}, 1.5 \mathrm{~km} / \mathrm{s}$ について解析した。

II 種地盤についての解析結果が Fig. 19 に示されてい る。実線は $V_{S T}=0.5 \mathrm{~km} / \mathrm{s}$ の場合のエネルギスペクト ルであり, 破線は $V_{S T}=1.0 \mathrm{~km} / \mathrm{s}$ の場合のエネルギス ペクトルである。細い実線は $V_{S T}=1.5 \mathrm{~km} / \mathrm{s}$ の場合で ある。 $T>2.0 \mathrm{~s}$ では $V_{S T}=0.5 \mathrm{~km} / \mathrm{s}$ の場合のエネルギ スペクトルが卓越する。一方, $V_{S T}=1.0 \mathrm{~km} / \mathrm{s}, 1.5$ $\mathrm{km} / \mathrm{s}$ では短周期領域（ $T<2.0 \mathrm{~s})$ でスペクトルの極值 が現れ，スペクトル形状は $V_{S T}$ が大きくなるほど急峻に なる。すなわち，岩盤による増幅は減少し，地盤の増幅 が強調されるようになる。図中のエネルギスペクトルは いずれも $h=0.1$ に対するものである。このような急峻 なスペクトルの極大值は減衰量 h に敏感である。した がって，このような急峻なエネルギスペクトルを設計用 エネルギスペクトルに考慮する際には，現実の構造物の hの值をより的確に評価する必要がある。現在， $T \leq$ $2.0 \mathrm{~s}$ の構造物に対しては終局強度設計法が適用されて おり，構造特性係数 $D_{s}$ 值の範囲は次のようなものであ $ろ^{19)}$

$$
0.25 \leq D_{s} \leq 0.5
$$

$D_{S}$ 值は，構造物の実強度の構造物が弾性にとどまる場 合の所要強度に対する比率と解釈できる。構造物の塑性 化によるエネルギ吸収が所要強度の低減に寄与する。一
方，弾塑性系を等価線形系に置換することができ，系の 非線形性は等価線形系における减衰定数に反映される。 弾性系の応答スペクトルの低減率として次式を取り上げ る1)。

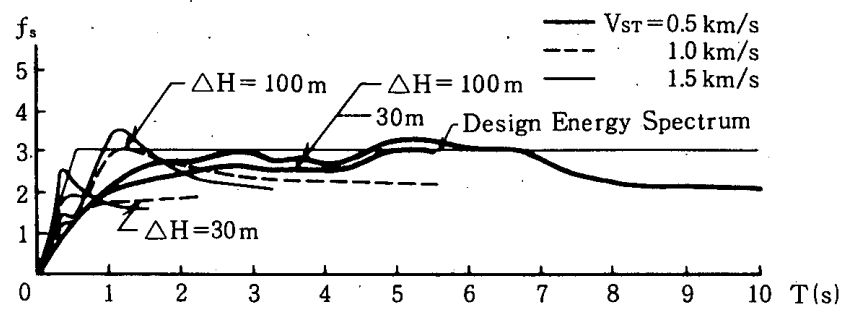

(a) Horizontal Ground Motions on the Ist Ground

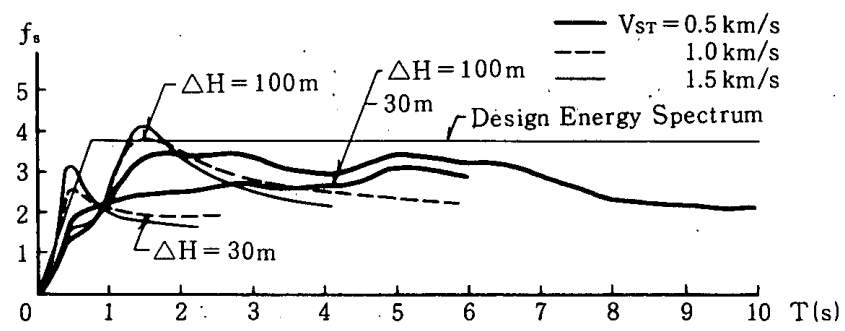

(b) Horizontal Ground Motions on the Ind Ground

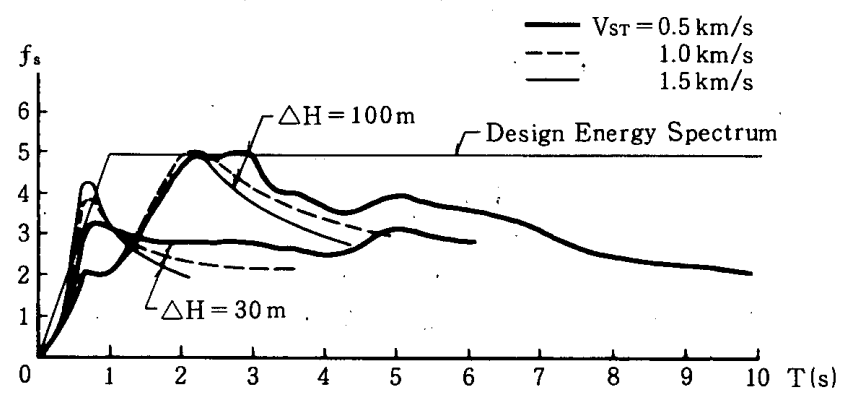

(c) Horizontal Ground Motions on the 1 ird Ground

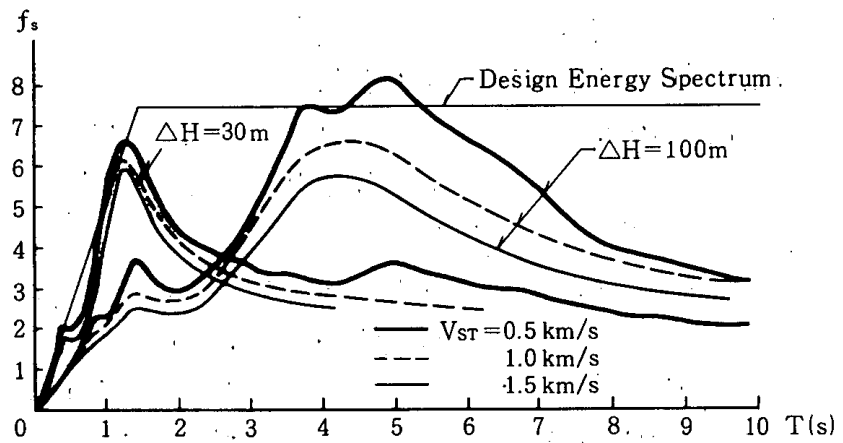

(d) Horizontal Ground Motions on the IV th Ground

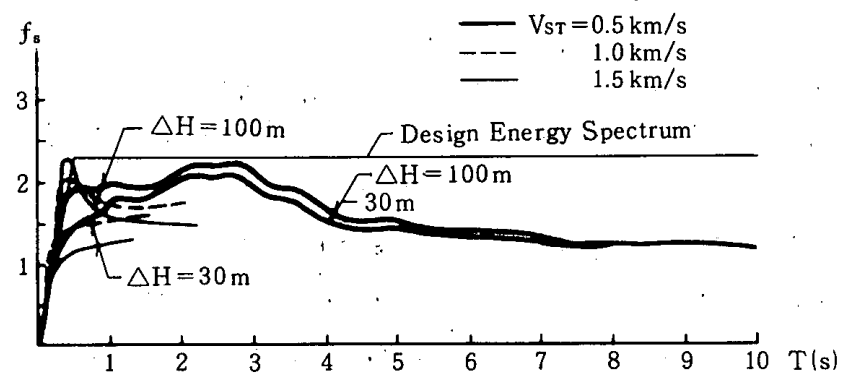

(e) Horizontal Ground Motions on Specified Ground

Fig. 20 Energy Spectra on Specified Grounds 


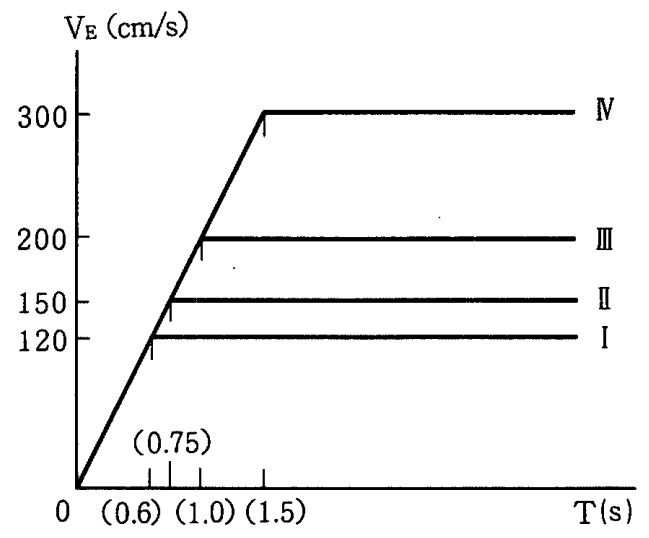

(a) Horizontal Ground Motions

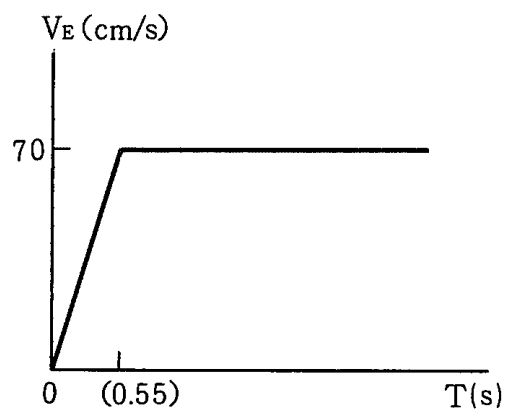

(b) Vertical Ground Motions

Fig. 21 Design Energy Spectra

$$
\frac{S(h)}{S(0)}=\frac{1}{1+3 h+1.2 \sqrt{h}}
$$

ここで, $S(0): h=0$ の系の応答スペクトル

$S(h)$ : 娍衰定数が $h$ なる系の応答スペクト ル

$S(h) / S(0)$ は $D_{s}$ 值と同等の意味を持つ。 $h=0.2$ の場合 の $S(h) / S(0)$ は 0.47 となる。この值を $D_{s}$ 值と見なせば, この値は（14）式のほぼ上限に位置する。すなわち，現 実の構造物の非線形性は減衰定数に換算すれば $h \geq 0.2$ に対応すると言える。以上の考察を踏まえて，長周期領 域のエネルギスペクトルを支配する $V_{s T}=0.5 \mathrm{~km} / \mathrm{s}$ の 場合は $h=0.1$ に対するエネルギスペクトルを，短周期 領域のエネルギスペクトルを支配する $V_{S T}=1.0 \mathrm{~km} / \mathrm{s}$, $1.5 \mathrm{~km} / \mathrm{s}$ の場合は $h=0.2$ に対するエネルギスペクトル を求め,これ等を総合して設計用エネルギスペクトルを 導く。Fig. 20 には得られた地盤表面上のエネルギスペ クトルを示す。表記法は Fig. 19 の場合と同様である。 $h=0.2$ を導入することにより, 短周期領域のスペクト ル形状はなだらかになる。Fig. 20(e) に示す鉛直地動 のエネルギスペクトルは, 表層地盤の影響をあまり受け ない。図中には ${ }_{s} V_{S T}=100 \mathrm{~m} / \mathrm{s}$ の場合を示してある。 Fig. 20 の各エネルギスペクトルをおおむね包絡するも のとして, 図中に示す bi-linear 型の $V_{E^{-}} T$ 関係が得ら れ，これを設計用エネルギスペクトルとする。Table 3 に示す $V_{E 0}$ を乗ずれば，設計用エネルギスペクトルとし
て Fig. 21 に示すものが得られる。鉛直地震動に対する エネルギスペクトルは地盤種別によらず単一のものとな る。エネルギスペクトルは 2 線分で表現でき， 2 線分の 交点の周期は図中の（）内に示されている。

総エネルギ入力 $E$ から減衰により消費されるエネル ギ入力 $W_{h}$ を除いて得られる損傷に寄与するエネルギ入 力 $E_{D}$ の速度換算值 $V_{D}\left(=\sqrt{2 E_{D} / M}\right)$ と $T$ との関係は 速度応答スペクトルとほぼ一致することが明らかにされ ている ${ }^{11}{ }^{20)}$ 。現行の建築基準法施行令 ${ }^{211}$ に示される 2 次設計用加速度応答スペクトルを円振動数で除して得ら れる速度応答スペクトルは，おおむね，Fig.21(a) に 示される I， II， III 種地盤のエネルギスペクトルと対応 している。すなわち，この速度応答スペクトルを 2 線分 で近似した場合の 2 線分の交点 $\left(T_{(s)}, V_{\max }(\mathrm{cm} / \mathrm{s})\right)$ は I 種地盤で $(0.64,100)$ II 種地盤で $(0.96,150)$ ， III 種地盤で $(1.28,200)$ である。しかし，ここに提案し たエネルギスペクトルは水平 2 方向入力の荷重効果の和 を表現していること，および減衰によるエネルギ吸収量 をも含んだ総エネルギ入力を表現している点で, 上記速 度応答スペクトルに比べて, より明確な意味を持ってい 万。

\section{4. 結 語}

地震基盤における地震動のエネルギスペクトルの形態 として最も単純な bi-linear 型を仮定し, これに適合し た人工地震波および一次元波動理論を用いて，地表面の エネルギスペクトルを求めた。本手法により，地表面で 得られた強震記録のエネルギスペクトルの形態を予測し 得た。

$M 8$ 級の地震動の地震基盤におけるエネルギスペクト ルのレベルを観測記録より推定し，代表的地盤の深さ方 向の弾性波速度分布を仮定して，代表的地盤の地表面の エネルギスペクトルを求め設計用エネルギスペクトルと して提案した。

ただし，提案されたエネルギスペクトルは，数少ない 強震観測資料に基づくものであり，定量化の精度に関し ては，より多くの観測資料を加えた今後の検討に俟つ所 が大きい。

\section{謝 辞}

地震記録等の資料収集に関して，清水建設 (株) 壇 一男氏，八ザマ(株)井上 超氏にご協力いただいた。

\section{参考文献}

1) 秋山宏：建築物の耐震極限設計, 東京大学出版会, 1980

2）壇 一男, 渡辺孝英, 田中貞二：遠方場 $\mathrm{S}$ 波の近似式に 基づく地震波形の半経験的合成法，日本建築学会諭文報 告集, 第 396 号, pp. 2 - 36, 1989.2

3）太田 裕，鏡味洋史：耐震工学上考慮すべき地震波の周 
期の上限と振幅の下限, 日本建築学会論文報告集, 第 249 号, pp. $53 \sim 60,1976.11$

4）田治見宏：建築振動学, コロナ社, 1965

5）大築志夫，金井 清：耐震設計，コロナ社，1961

6）阿部康彦, 小林喜久二, 大島 豊, 真下 貢, 小林啓美 : 地震動の上下動・水平動スペクトル振幅比の特性とそ の応用に関する研究 (その 3), 日本建築学会大会学術講 演梗概集, pp. 403 404, . 1991

7）小林啓美, 長橋純男 : 地表で観測された地震動の周期特 性から求めた地盤の增幅特性と地震基盤における地震動 の性質, 日本建築学会論文報告集, 第 240 号, pp. 79 90, 1976.2

8) Jennings, P.C., Housner, G.W. and Tsai, N.C. : Simulated Earthquake Motions for Design Parposes, Proc. 4th W.C.E. E., Santiago, 1(A1), pp. 145 160, 1969. 1

9）日本建築学会：地震荷重一その現状と将来の展望, 丸善, 1987

10）渡辺丹, 藤堂正喜：設計用模擬地震動に関する研究, 日本建築学会論文報告集，第 303 号，pp. $41 ５ 1$, 1981.5

11) Anderson, J. G., Bodin, P., Brune, J. N., Prince, J., Singh, S.K., Quaas, R. and Onate, M. : Strong Ground Motion from the Michoacan Mexico Earth quake, Science, Vol.233, pp. 1043 1049, 1986.9

12）翠川三郎，小林啓美：地震動の地震基盤からの入射波ス
ペクトルの性質, 日本建築学会論文報告集, 第 273 号, pp. 43〜 52, 1978. 11

13）土田 肇, 上部達生：El Centro および Taft の強震計の 設置資料, 地震工学振興会ニュース, No. 69, pp. 9 19, 1983.3

14) Kanai, Ko: A study of Strong Earthquake Motions, Bull. Earthq. Res. Iust., Vol. 36, pp. 295 310, 1958

15）田中貞二：最近の被害地震における最大加速度の大きさ について、第 7 回地盤振動シンポジウム, pp. 3-8, 1979.3

16) Guteuberg, B and Richter, C.F. : Earthquake Magnitude, Intensity, Energy and Acceleration, Bull. Seism. Soc. Amer., Vol. 46, pp. 163 191, 1956

17）大場新太郎，鳥海 勲：大阪地盤の振動特性に関する研 究, 日本建築学会大会学術講演梗概集, pp. 487〜 488, 1970

18) Ohsaki, Y, and Iwasaki, R. : On Dynamic Shear Moduli and Poisson's Ratio of Soil Deposits, Research Report 73-02, University of Tokyo, 1973

19）日本建築学会：建築耐震設計における保有耐力と変形性 能 (1990), 丸善, 1990

20) Housner, G. W. : Limit Design of Struetures to Resist Earthquakes, Proc. 1st WCEE, pp. 5-1-13, 1956

21）建築基準法施行令, 1981.6

(1992 年 12 月 10 日原稿受理, 1993 年 5 月 11 日採用決定） 